Ceren BILGIN GÜNEY

Devrim Bülent DANIŞMAN

Şafak Nur ERTÜRK BOZKURTOĞLU

Fatma YONSEL

http://dx.doi.org/10.21278/brod69204

\title{
DETERMINATION OF SEDIMENT ACCUMULATION PATTERN IN A DOUBLE BOTTOM BALLAST TANK MODEL
}

\author{
UDC 629.5.018.71:629.5.045.63: 629.5.062.2
}

Original scientific paper

\begin{abstract}
Summary
Ballast tank sediments may cause several problems in a wide range changing from environmental to economical. Its contribution to biological invasion is an important concern. Thus, the sediment management is included as an integral component of the "The International Convention on the Control and Management of Ships' Ballast Water and Sediments". The reduction of the amount of the sediment to be removed is of great importance for management issues. Therefore, the convention underlines that ships should be designed and constructed with a view to minimize the uptake and undesirable entrapment of sediments and facilitate removal of sediments. Design and construction solutions can effectively be developed after determination of the problem areas. In this study, sediment accumulation pattern and problem areas in the ballast tank model of a longitudinally framed double bottom tanker is determined. The problem areas are found to be at the mid-section of the tank closer to the centre girder.
\end{abstract}

Key words: Ballast tank; Sediment accumulation; Tank design; Invasive species

\section{Introduction}

Transfer of organisms by ship's ballast water has received widespread attention for almost decades starting from 1970's [1]-[4]. The recognition of negative and irreversible impacts of organisms carried in the ballast tanks has triggered many national and international attempts. The International Convention on the Control and Management of Ships' Ballast Water and Sediments at the auspices of the International Maritime Organization (IMO) brings about the measures in the international level aiming to prevent the spread of harmful aquatic organisms from one region to another. The convention entered into force on 8th September 2017. Besides the IMO convention the United States Coast Guard (USCG) published a final rule in March of 2012 to implement ballast water discharge standards. Even though it is a national legislation, it will apply to all vessels discharging in the U.S. waters that take on ballast water outside the U.S. and Canadian Exclusive Economic Zone. D-2 Standards of IMO convention along with the USCG Ballast Water Discharge Standards Final Rule are the two predominant legislations around the globe. Both legislations bring about the limitations on the allowable number of living organisms within a certain size class of organism in the ballast water [5]. 
There are more than 70 ballast water treatment systems which have received the Type Approval according to IMO Guidelines for Approval of Ballast Water Management Systems (resolutions MEPC.175 (58) and MEPC.228 (65)) [6]. The decision criteria for selecting ballast water treatment systems are generally based on the ship specifications or/and treatment system characteristics [7]. However the ballast water characteristics are also effective on the system performance [8]-[11] and these systems are mostly effective on organisms which are living in the water phase. On the other hand, ballast tanks of the ships cannot be completely emptied during de-ballasting [12]. Significant amount of sediment may accumulate in some ships during their operations through the years, which give rise to a further invasion risk. The soil sediment drawn by ballast water is mostly in the form of clay ( $2 \mu \mathrm{m}$ or less), silt $(2-63 \mu \mathrm{m})$ and sand (63 $\mu \mathrm{m}-2 \mathrm{~mm}$ ) [13]. On the other hand, most of the ballast water treatment systems available on the market use filters in the first stage of the treatment process. Typical backwash filters used in these systems are mostly capable to remove particles larger than $40-50 \mu \mathrm{m}$, which is above the particle size of the sediment drawn by the ballast water. The studies have shown that none of the ballast water treatment methods are capable of eliminating all types of organisms and each method used within the ballast water treatment systems have its own limitations [10], [14]. As a consequence, there may also be living organisms left in the ballast tanks. The size limitation for allowable living organisms is another concern as many marine organisms have the capability to form resting stages and cysts which are smaller than their vegetative cells and a lot are $<10$ $\mu \mathrm{m}$ in minimum dimensions [15]. There are a number of studies which draw attention to the invasion risk of organisms within the wide range of taxa and different life stages, which are hosted by the sediment of the ballast tanks [16]-[23]. Once the organisms survive a treatment method, the capability of long term germination of organisms found in ballast sediment [19] and the possibility of in situ hatching of dormant stages in the ballast tanks are important concerns in terms of invasion risk [21].

In addition to invasion risk, sediments that accumulate in the ballast tanks pose several problems in a wide array [24]. One of the concerns is about human health. If a ship has been installed with a ballast water treatment system which makes use of active substances, the sediment may play role as a repository for disinfection byproducts. This in turn increases the human exposure risk during several occasions such as the ballast water sampling, tank maintaining (sediment cleaning) and tank inspection [25]. The sediments also may be an important sink for heavy metals and compounds that are originated from the deterioration of tank plates used for the structural members and tank coating residues [13], [26], [27] which brings about potential ecological risks. On the other hand, the accumulation of the sediment at the bottom of the tanks, along with the other impurities and life forms hosted by the sediment, increases the corrosion risk through different mechanisms [28]-[31]. Besides all, the amount of the sediment accumulated within the tanks may reach up to 100s of tons depending on the vessel type and capacity [19], [32]. This may in return cause a cumulative loss of income through the years between tank cleaning which generally takes place during dry-dockings.

There are several factors affecting the sediment accumulation in a ballast tank. The flow regime in the ballast tank is one of the important factors. The structure of the ballast tanks varies from ship to ship and depends on where it is located on a single ship. However, the complex geometry due to longitudinal and transversal structural members (such as bottom longitudinals, girders, solid floors) used to maintain the ship strength in most ballast tanks is a common issue. This complexity also causes a complex flow regime during ballasting and de-ballasting operations. The tanks contain many compartments separated by longitudinal and transversal structural members and openings on these members. There are many potential dead spots in the tanks. During ballasting and de-ballasting operations, these spots with very low local flow velocities are susceptible to sediment accumulation [33] and besides, the positions of inlet and outlet directly affect the flushing efficiency [34], [35]. Sturtevant et. al. also observed that the 
sedimentation pattern differs in the ballast tanks depending on both the proximity of the location to the bell-mouth (ballast intake/pump-out port) and openings on the tank members [36].

The International Convention on the Control and Management of Ships' Ballast Water and Sediments of IMO brings obligations for ships. Along with other terms included in the Convention, Regulation B.5 states that ships should be designed and constructed with a view to minimize the uptake and undesirable entrapment of sediments. The Marine Environment Protection Committee (MEPC) of IMO also developed "Guidelines on design and construction to facilitate sediment control on ships (G12)" (resolution MEPC.209 (63)) to assist designing ships to minimize the retention of sediment [37]. The main purpose of the present study was to experimentally determine the sediment accumulation pattern in a longitudinally framed double bottom tank model. By identifying the accumulation pattern, it will be possible to identify problem areas and to develop strategies for target areas to avoid sediment accumulation.

\section{Materials and Methods}

\subsection{Experimental System}

The experimental system consisted of three components (Fig. 1). A ballast tank model was the main component of the system. A roll simulator component provided regular motion for the tank model. The third component was the sediment and water mixing tank. This tank was used to prepare a mixture (hereinafter will be referred to as ballast mixture) that would be used to fill the ballast tank instead of ballast water. The ballast mixture was filled directly into the ballast tank model with a pipe system. The tank was also emptied by the same circuit.

The ballast tank model (Fig. 2) was constructed as a 1/20 scale model of a real longitudinally framed tanker double bottom ballast tank structure. The model contained all the main components available in the real tanker double bottom ballast tank. The holes and apertures that would allow water flow through the compartments of the tank model (i.e. manholes, lightening holes on the longitudinal and transversal structural members, small apertures opened in the lower corners of the used profiles, cutouts at the intersection of the bottom longitudinal and transverse floors, scallops) were also present with the scaled dimensions. The model was separated longitudinally by a continuous centre girder. Each side of the model had an inlet / outlet at the rear wall close to the continuous centre girder. Left side of the model considered as the port side of the real ship and the right side of the model considered as the starboard side of the ship. Each side had 8 stations and 24 compartments sectioned by transversal floors and longitudinal girders (Fig. 3). The compartment rows were numbered from 1 to 8 starting from bow side to the aft side of the model; compartment columns were labelled as A, B, C from the port side towards the centre line and labelled as D, E, F from the center line to the starboard side of the model. The model was placed on the carrier stand of the roll simulator. Although ships have six degrees of freedom, only the roll motion was taken into account for simplicity.

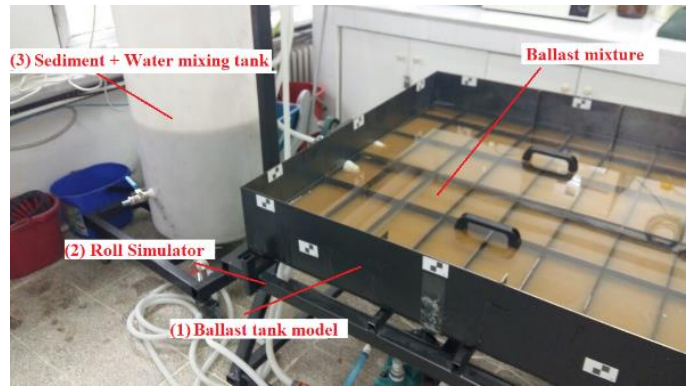

Fig. 1 Experimental system

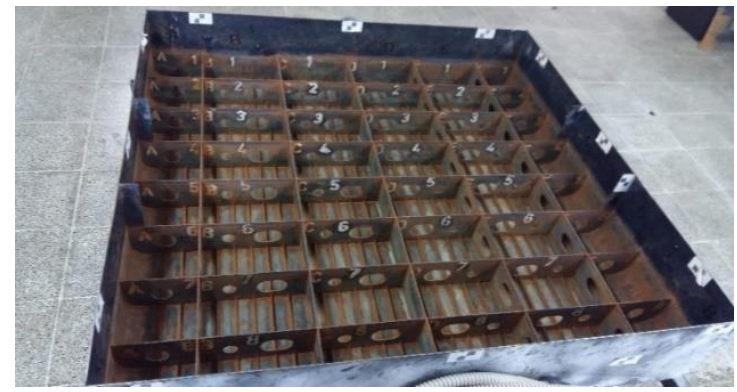

Fig. 2 Ballast tank model 


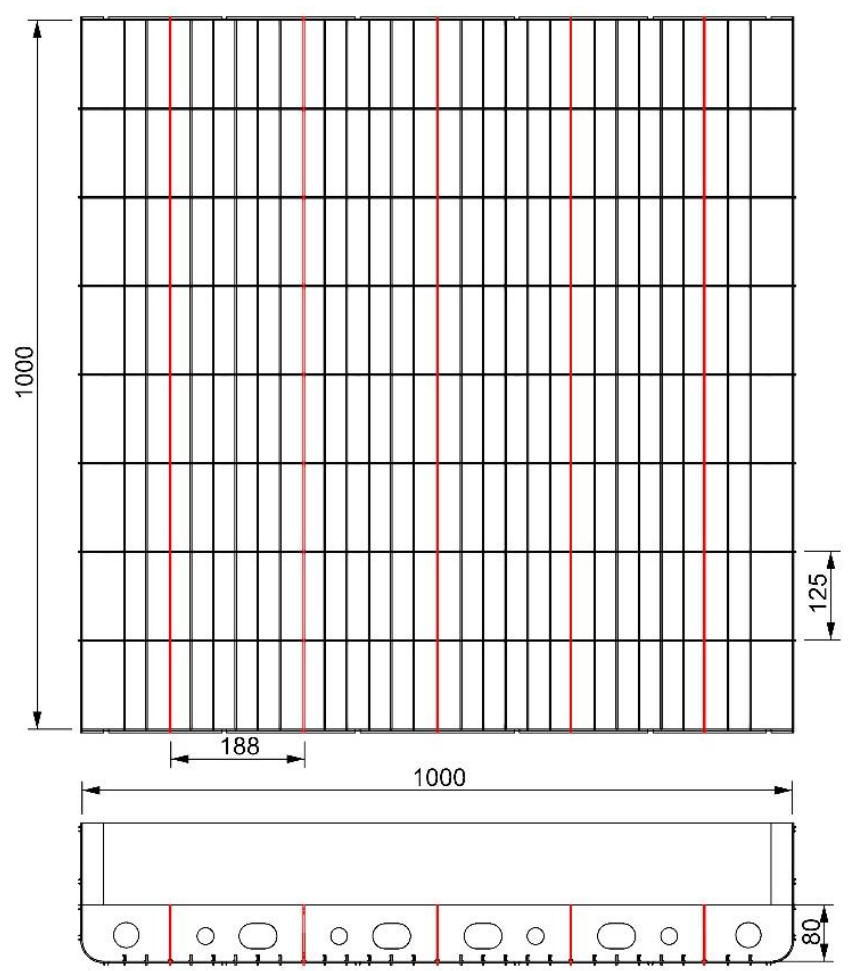

Fig. 3 Technical drawing of the model ballast tank. (Dimensions are given in $\mathrm{mm}$ )

\subsubsection{Preparation of ballast mixture}

Sediment directly from the sea bottom would contain different fractions depending on the time and location where the sediment was drawn. This would adversely affect the comparability of the results of replicate experiments. For this reason, it was decided to use industrially manufactured clay instead of sea sediments and commercially available bentonite clay was used to ensure homogeneity.

The ballast sediment mixture was prepared as a suspension of bentonite clay by mixing tap water with bentonite in the mixing tank. The mixing tank was installed with two mutually perpendicular blade systems. The first blade was situated at the bottom of the mixing tank while the other is situated $50 \mathrm{~cm}$ above the bottom. The blades had a two-way rotation with intervals to prevent sedimentation at the bottom and ensure well mixing in the water column. The ballast mixture contained $3 \mathrm{~g} / \mathrm{L}$ sediment in suspension. The sediment concentration was chosen to be 10 times the suspended particulate matter of a standard harbour condition scenario [38], which was compatible with the sediment concentrations in harbours with high sediment concentrations [39]. Since the sediments contained in the ballast water were saturated with water in the real life conditions, the mixture was stirred in the mixing tank for 24 hours prior to it was taken to the tank model for the experiments.

The reason behind the choice of clay is mainly the geometric dimension of the particles. Clay minerals are clay-sized $(<2 \mu \mathrm{m})$ fraction of soils [40]. Most of the sediments that accumulate in ballast tanks are in clay and silt size $(<63 \mu \mathrm{m})$ [13], [25]. As a result, the particle size to be selected had to be below $63 \mu \mathrm{m}$ when scaled up to real size. On the other hand, in the ballast tank model, the bottom apertures (located where structural members meet the bottom floor) that provide water passage between the compartments were quite narrow spaces. When the real ship was scaled down to the model, the dimensions of these apertures decreased from centimetres to millimetres (i.e., the diameter of the semicircle shaped scallops decreases from 
$120 \mathrm{~mm}$ to $6 \mathrm{~mm}$, and the diameter of the quarter circle shaped apertures decreases from 36 $\mathrm{mm}$ to $1.8 \mathrm{~mm}$.). The particle size to be selected should not cause clogging more than real life condition. And lastly, the average capacity of pre-treatment technologies (filter, hydrocyclone, etc.) of the ballast water treatment systems present in the market were taken into account. It was determined that the significant number of the systems is capable of disposing particles which are sized $40 \mu \mathrm{m}$ and above. The use of clay with a particle size $<2 \mu \mathrm{m}$ would correspond to a particle size $<40 \mu \mathrm{m}$ when scaled to real condition. Within the framework of the above criteria, clay size found to be appropriate in terms of geometric dimensions. On the other hand, different types of clay were tested preliminarily and bentonite found to be appropriate in terms of sedimentation duration in the water column within the purpose of the experiment.

\subsection{Experimental plan}

This work was carried out to determine the sediment accumulation pattern in a double bottom ballast tank of a conventional longitudinally framed tanker. The prepared ballast mixture was filled into the model of the ballast tank. Three ballast condition voyage of a tanker (each lasted $\sim 4.5$ days) was simulated with the roll simulator. The study was conducted assuming that each ballast voyage took place in a 3-4 sea state (Beaufort number 4-5) condition (roll angle $\varphi=5^{\circ}$, rolling period $\mathrm{T}=15.65 \mathrm{~s}$ ), which is the most common sea state condition [41] that the commercial ships operate at. The working duration of the system and the number of times of filling and discharging were determined depending respectively on the duration of the simulated ballast voyage and the number of ballast voyages. The experimental parameters are given in Table 1.

Table 1 Experimental parameters

\begin{tabular}{|l|l|l|}
\hline Parameter & Real Tank & Model \\
\hline Scale & - & $1 / 20$ \\
\hline Beam $[\mathrm{m}]$ & 20 & 1 \\
\hline Length of the ballast tank $[\mathrm{m}]$ & 20 & 1 \\
\hline Height of the ballast tank [m] & 1.6 & 0.08 \\
\hline Sea state & $3-4$ & $3-4$ \\
\hline Roll angle $\left[{ }^{\circ}\right]$ & 5 & 5 \\
\hline Roll period $[\mathrm{s}]$ & 15.65 & 3.5 \\
\hline Voyage duration $[\mathrm{h}]$ & 108 & 24 \\
\hline Voyage repetition & 3 & 3 \\
\hline
\end{tabular}

The ballast tank model was filled up to $90 \%$ of its capacity with the ballast mixture and then the roll simulator was started. After 24 hours of simulation, the ballast mixture was discharged through the outlet at the rear side of the model. As in the real discharge condition, $5^{\circ}$ of trim to the aft side of the model was provided at the end of the process to ensure the maximum discharge volume. After the discharge process was completed, the new ballast mixture was taken on the remaining sediment and the system was restarted for 24 hours. Then the same process was repeated once again. The experimental trial was completed after simulating a total of three ballast cycles. Three trials were conducted under the above mentioned conditions.

At the end of the experiment, the sediment collected from each compartment was taken into the beakers which had been previously weighed. The sediment in the beakers was dried at a temperature of $103-105^{\circ} \mathrm{C}$ until a constant weight was obtained. The total solids accumulated in each compartment were then determined by analytic scale by measuring the weight gain of the evaporation residue in the sediment collected from the respective compartments. 


\subsection{Uncertainty Analysis}

The uncertainty analysis was carried out by following the International Towing Tank Conference (ITTC) Quality Manual 7.5-02-02-02. Major experimental error resources were considered to be the model geometry, sediment collection and the weight measurement device.

\section{Model geometry and measurement equipment:}

The model should be manufactured either to be geometrically similar to the drawings or mathematical model describing the hull form. Even though great effort is given to the task of building a model, no model manufacturing process is perfect and therefore each model has an error in form. The influence of an error in the hull form affects the total volume of the model. Therefore, the bias errors due to model manufacture error both in the model dimensions and the volume were taken into account. Calculation of the bias error due to model manufacture precision allowed by the ITTC is given in Table 2 . Each dimension is varied $\pm 1 \mathrm{~mm}$ to reflect the maximum manufacture error. The precision limit of the weight measurement equipment was given as $0.0001 \mathrm{~g}$ by the manufacturer.

Table 2 Bias error from the model manufacture process.

\begin{tabular}{|l|l|l|l|l|}
\hline \multirow{2}{*}{} & \multirow{2}{*}{$\begin{array}{l}\text { Target Model } \\
\text { Dimensions }\end{array}$} & \multicolumn{2}{|c|}{ Model Dimensions } & Total Model \\
\cline { 3 - 4 } & Manufacture Error \\
\hline Length $[\mathrm{mm}]$ & 1000 & 999 & Maximum & 2 \\
\hline Beam $[\mathrm{mm}]$ & 1000 & 999 & 1001 & 2 \\
\hline Depth $[\mathrm{mm}]$ & 70 & 69 & 1001 & 2 \\
\hline Volume $[\boldsymbol{L}]$ & $\mathbf{7 0 . 0 0 0}$ & $\mathbf{6 8 . 8 6 2}$ & 71 & $\mathbf{7 1 . 1 4 2}$ \\
\hline
\end{tabular}

\section{Data Evaluation:}

As the port side and starboard side of the tank are symmetrical with respect to the continuous centre girder and have their separate ballast intake/pump-out ports, the results obtained from the tanks on both sides are evaluated together. First, uncertainty analysis was carried out for 6 data sets ( 2 data sets $\times 3$ Trials).

According to the uncertainty assessment method recommended in the ITTC Quality manual 7.5-02-02-02 the precision limit for a single record is calculated as,

$$
P(s)=2 \times S D e v
$$

where $s$ stands for a single run and SDev is the standard deviation, and total uncertainty for the multiple records can be calculated as,

$$
P(M)=\frac{P(s)}{\sqrt{M}}
$$

where $M$ is the number of records.

\section{Results}

Considering the weight of the accumulated sediment in the tank bottom will vary depending on the conditions, the test results were evaluated proportionally to be able to have a general perspective on the issue. The proportion of the solid material obtained from each compartment to the total solid material collected from all the compartments of the tank considered (i.e. port side and starboard side of the tank model) were taken into account. For each trial, the sediment accumulation rates (SARs) of each compartment in the port side and starboard side tanks are presented in the contour graphs given in Fig. 4, Fig. 5 and Fig. 6, respectively. The red line separating the model longitudinally represents the continuous centre 
girder. The left hand side of the figure gives the sediment accumulation rates within the port side of the model, while the right hand side of the figure gives the sediment accumulation rates within the starboard side of the model. The $100 \%$ SAR indicates the total sediment accumulation amount in each side (port and starboard sides) of the tank model.

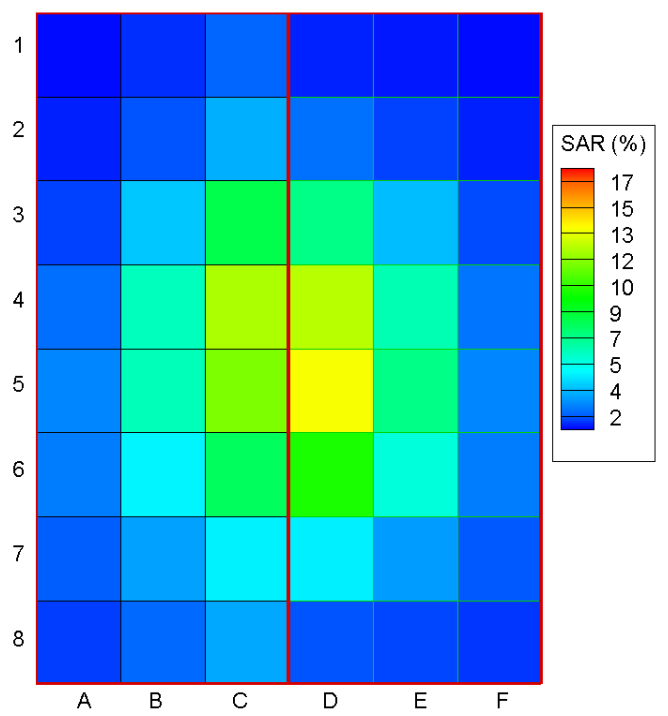

Fig. 4 The sediment accumulation rate-SAR (Trial 1)

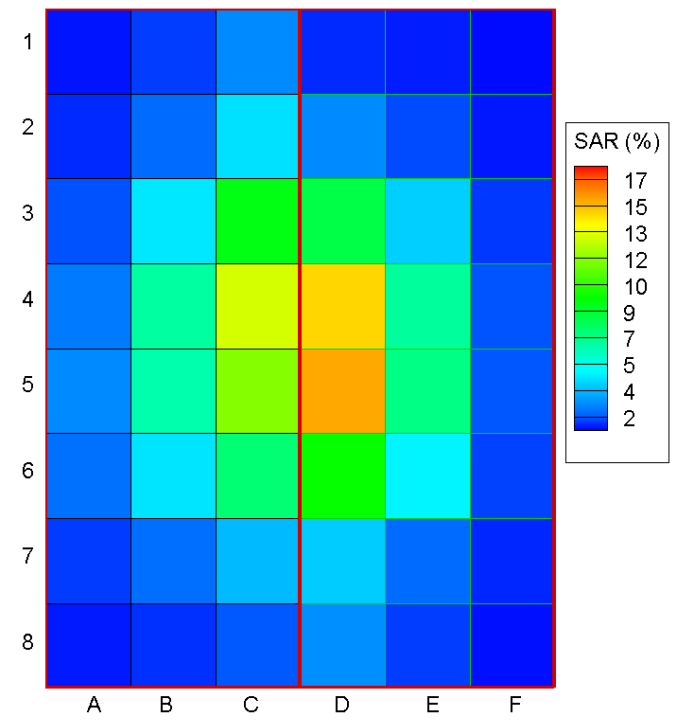

Fig. 5 The sediment accumulation rate-SAR (Trial 2)

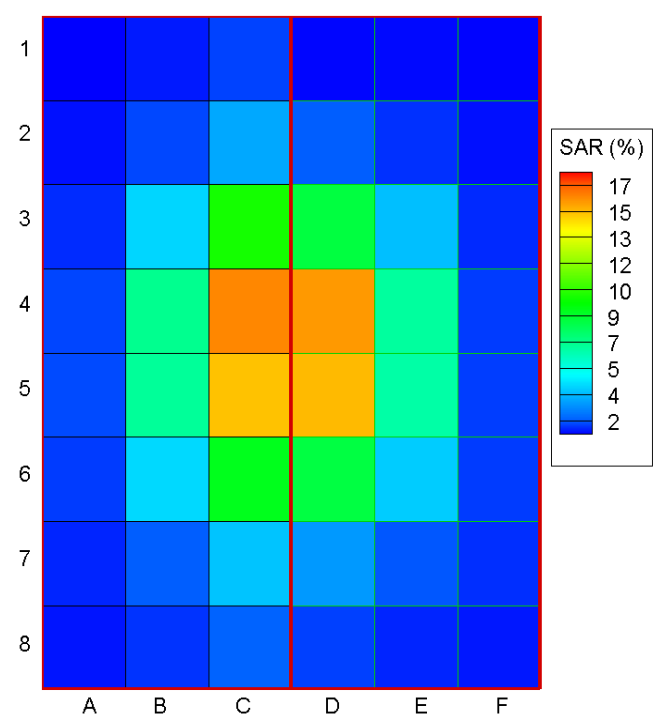

Fig. 6 The sediment accumulation rate-SAR (Trial 3)

When the graphs are examined, most of the sediment appear to accumulate intensively in the C3-C4-C5-C6 compartments on the port side and in the D3-D4-D5-D6 compartments on the starboard side. These compartments are located next to the continuous centre girder. The sediment accumulation increases towards the centre of the model, and decreases in the longitudinal and horizontal directions with increasing distance from the centre of the model.

\section{Discussion}

The observed sediment behavior is a result of the boundary layer formation along the compartment side walls and the bottom. During the rolling motion of a tank that is filled with water, drag will form on the tank walls due to the boundary layer formation. The water right at the sides of the compartments and all along the bottom, will be moving slower than the rest of the liquid in the tank due to the boundary layer effect. All that water pushing up against the 
sides of the compartments establishes a pressure gradient, with higher pressure towards the outside of the tank. The slow-moving water is displaced and when it hits the sides of the tank, it drops downwards, and when it gets to the bottom of the tank, and meets the relatively slowmoving water there, it's forced inwards. Once it gets to the middle section it's forced upwards, and the cycle continues over and over again.

The time evolution of the liquid motion, including the free surface deformation at regular intervals during one period of the tank motion [42] is given in Fig. 7. In their study, [42] Jung et. al. showed that the fluid flows mainly in the same direction as the tank motion which supports the flow pattern explained above.

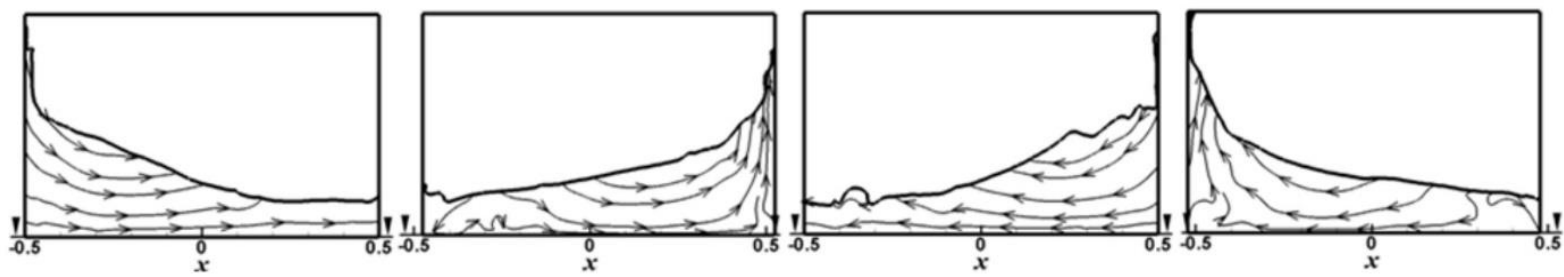

Fig. 7 Flow streamlines in a tank at $=1 / 4 \mathrm{~T}, \mathrm{t}=2 / 4 \mathrm{~T}, \mathrm{t}=3 / 4 \mathrm{~T}$ and $\mathrm{t}=4 / 4 \mathrm{~T}[42]$

Sediments in the water are too heavy to be lifted up by the upward flow in the tank, but they get caught up in that roll and are directed towards the centre girder of the tank where they accumulate.

The results from the three trials mentioned in the results section were used to generate a general perception of the sediment distribution pattern in the ballast tank model. In this context, the mean value of the three trials was calculated and columns that are symmetrical with respect to the centre girder (starboard side and port side) were evaluated as different data sets. The assumption of different data set is based on the symmetric structure of the model. In the model, the starboard side and port side sections work as separate ballast tanks. They have their own inlet/outlet and their motion is symmetrical with respect to the centre girder, which is watertight.

In Fig. 8, the sediment accumulation in each row from 1 to 8 is given. The sediment accumulation is intensified in the $\mathrm{C}$ and $\mathrm{D}$ columns which are symmetrically located on each side of the centre girder where the amplitude of the roll motion is the smallest. This causes a slow down on the sediment motion in the compartments closer to the centre of symmetry. On the other hand, due to the boundary layer formation on the exterior watertight walls at the bow and aft sides the sediment is headed towards the centre which corresponds to the rows 4 and 5 . 


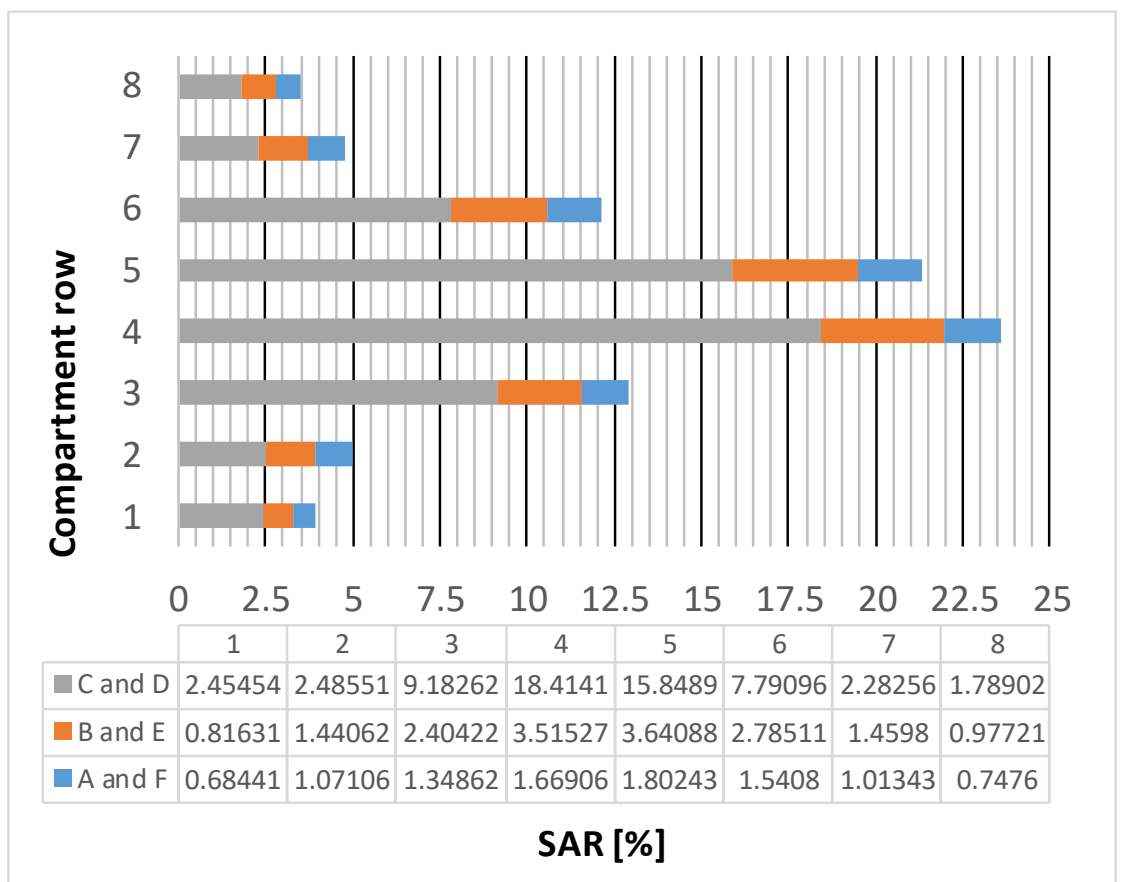

Fig. 8 The sediment accumulation rates (SAR) in each compartment row in the ballast tank model

Considering the above mentioned approach, an uncertainty analysis was made according to the ITTCS quality manual 7.5-02-02-02 to obtain more refined results from the experimental study. The mean value and its rate of uncertainty variation depending on the number of records are given in Table 3 for the nearest columns ( $C$ and $D)$ to the center girder where the maximum sediment accumulation was observed. Rate of uncertainty values were calculated by using Equation 2 in Section 2. The mean value and the standard deviation of all tests were calculated and change of uncertainty for each data set is presented in this table.

Table 3 Uncertainty values calculated for each data set for columns C and D

\begin{tabular}{|c|c|c|c|c|c|c|c|c|}
\hline & & & \multicolumn{5}{|c|}{ Rate of uncertainty to the mean value for each data set (DS) } \\
\hline & & Standard & & & & & \\
Row & Mean [g] & Deviation [g] & DS-1 & DS-2 & DS-3 & DS-4 & DS-5 & DS-6 \\
\hline 1 & 3.8749 & 1.9023 & 0.9819 & 0.6943 & 0.5669 & 0.4909 & 0.4391 & 0.4008 \\
\hline 2 & 4.4176 & 1.9502 & 0.8829 & 0.6243 & 0.5098 & 0.4415 & 0.3949 & 0.3605 \\
\hline 3 & 17.2695 & 5.5349 & 0.6410 & 0.4533 & 0.3701 & 0.3205 & 0.2867 & 0.2617 \\
\hline 4 & 40.0780 & 5.3899 & 0.2690 & 0.1902 & 0.1553 & 0.1345 & 0.1203 & 0.1098 \\
\hline 5 & 32.8829 & 4.1369 & 0.2516 & 0.1779 & 0.1453 & 0.1258 & 0.1125 & 0.1027 \\
\hline 6 & 18.8747 & 2.6081 & 0.2764 & 0.1954 & 0.1596 & 0.1382 & 0.1236 & 0.1128 \\
\hline 7 & 5.7357 & 2.0378 & 0.7106 & 0.5024 & 0.4102 & 0.3553 & 0.3178 & 0.2901 \\
\hline 8 & 5.1616 & 1.9424 & 0.7527 & 0.5322 & 0.4345 & 0.3763 & 0.3366 & 0.3073 \\
\hline
\end{tabular}

In Fig. 9, the variation of the uncertainty can be seen by means of the number of records. This figure shows that total uncertainty can be reduced to less than $10 \%$ of the mean value provided that 6 and more records of the sediment collection are available.

The results obtained from the uncertainty analysis shows that the general perception of the sediment distribution pattern given in Fig. 8 is in an acceptable error range. The sediment amount will naturally change due to several factors (i.e. sediment load of the port, operational conditions, duration after the last tank cleaning). However, the accumulation patterns tend to be similar. 


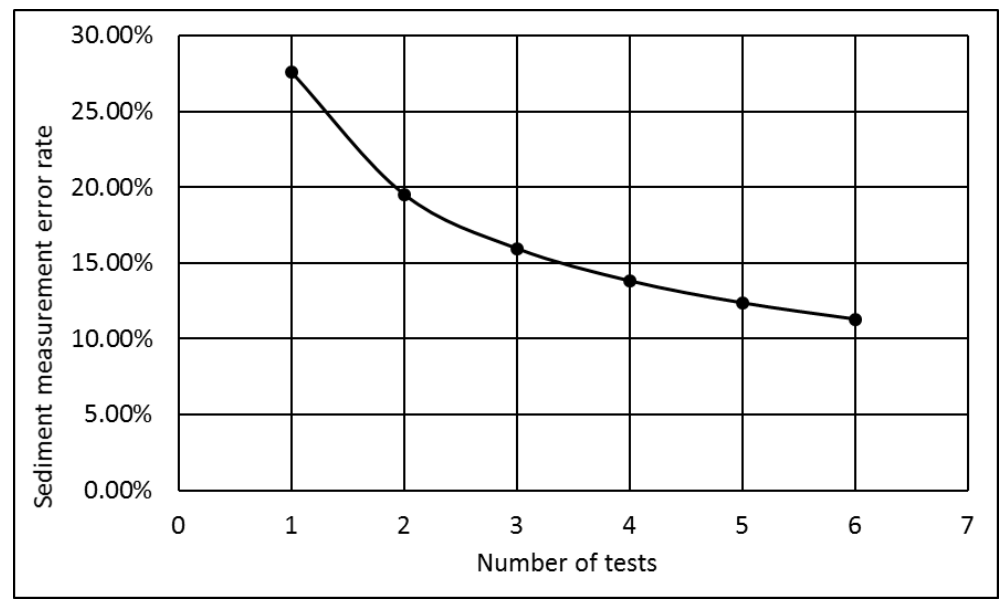

Fig. 9 Sediment measurement error variation vs. the number of tests

Fig. 10 shows the error distribution along the rows of the subject column. The measurement error rate gets smaller with the increase of the sediment collection amount.

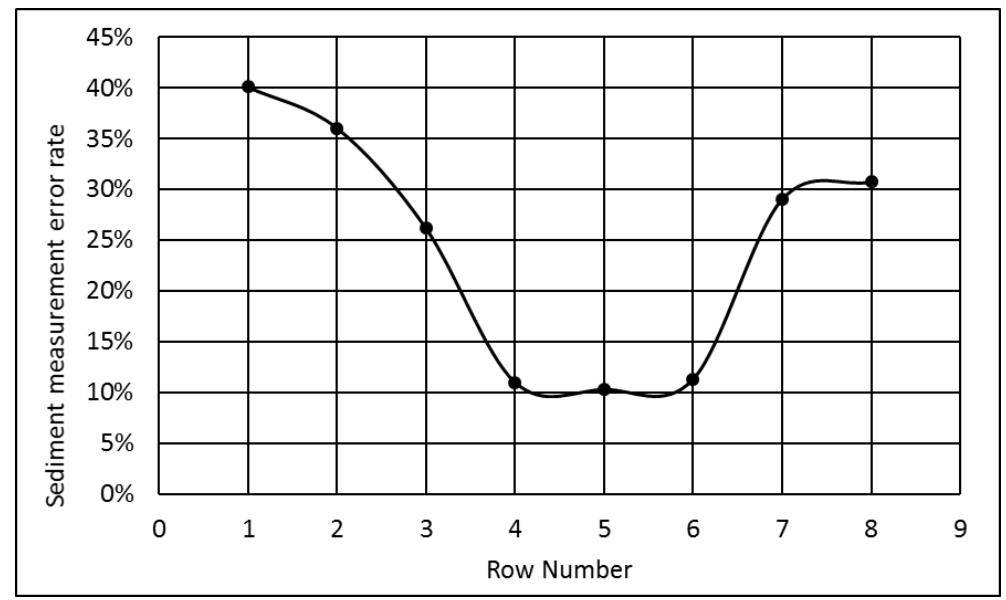

Fig. 10 Sediment measurement error rate vs. the place taken.

In Fig. 11, error bars were placed on the mean value of 6 sediment collection records. It is found that the total uncertainty can be as low as $10 \%$ at places with the highest sediment accumulation.

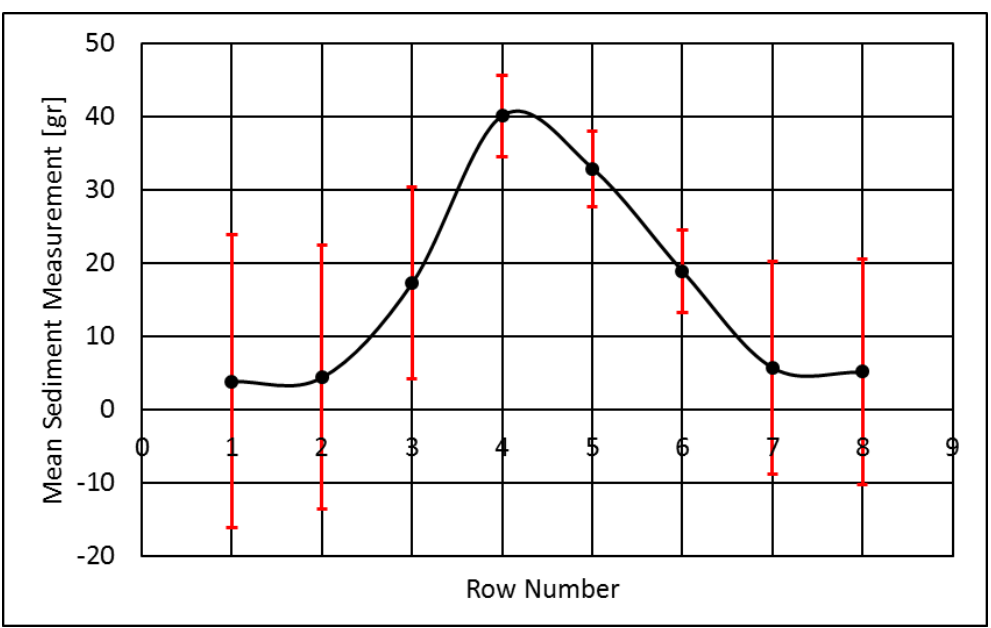

Fig. 11 Mean sediment measurement with error bars according to the uncertainty analysis. 


\section{Conclusion}

Sediment management is an integral component of "The International Convention on the Control and Management of Ships' Ballast Water and Sediments". Due to the nature of the sediments, management consists of several stages, processes and procedures [43]. The best strategy for ballast management is avoiding sediment uptake with the ballast water. However, once the sediment is uptaken with the ballast water, the management starts with the collection of the sediment from the tank's bottom, which is a tedious and demanding task. Therefore, the reduction of the amount of sediment to be collected and managed is of great importance. The regulation B.5 of the International Convention on the Control and Management of Ships' Ballast Water and Sediments underlines that ships should be designed and constructed with a view to minimize the uptake and undesirable entrapment of sediments and facilitate removal of sediments. From this perspective, developing the design strategies that go in line with the "2012 Guidelines on Design and Construction to Facilitate Sediment Control on Ships (G12)"[37] developed by Marine Environment Protection Committee of IMO is crucial. However, effective design and construction solutions can be developed after determination of the problem areas.

In this study, sediment accumulation pattern in the ballast tank model of a longitudinally framed double bottom tanker is determined in order to find out the target area for developing effective design strategies. The highest sediment accumulation rates are determined at the compartments, which are neighboring the central continuous girder around the mid-part of the tank model. These results are also consistent with the preliminary results of the authors [44].

In their technical paper, Prange and Pereira [12], propose some simple modifications in ballast tanks that include modification in the de-ballasting system, some minor alterations in the tank design and injection of water against the bottom of tanks. Yuan et. al. [45] also proposes a flushing system to re-suspend the accumulated sediments at the bottom and circulate it through a hydrocyclone for separating. These and other strategies would be more effective if the accumulation pattern is taken into account. A combination of several strategies developed depending on the accumulation pattern can be both effective and more feasible.

The findings of this study suggest that re-suspension would be beneficial especially at the compartments neighboring the central continuous girder around mid-part of the tank model, while minor alterations alone can be sufficient at the outer surrounding compartments. These precautions will also decrease the sediment accumulation amount through the duration between two tank cleaning processes.

Although the ships have six degrees of freedom, the rotational motions (i.e. roll, pitch, yaw) are dominant for triggering the sediment motion in the tanks. In this study, only the roll motion was taken into account for simplicity. Future work that will include the pitch and yaw motions in addition to the roll motion will lead to more accurate accumulation patterns. This will benefit the strategies for avoiding sediment accumulation in the tanks.

\section{ACKKNOWLEDGEMENT}

This study is conducted within the ongoing project titled "Conceptual Ballast Tank Design for Reducing Sediment Accumulation" that is supported by the Scientific and Technical Research Council of Turkey (TUBITAK) with the Grant No: 115Y740.

\section{REFERENCES}

[1] J. C. Medcof, "Living marine animals in a ships ballast water," Proceedings National Shellfisheries Association, vol. 65. pp. 11-12, 1975.

[2] I. C. Davidson and C. Simkanin, "The biology of ballast water 25 years later," Biol. Invasions, vol. 14, no. 1, pp. 9-13, 2012. https://doi.org/10.1007/s10530-011-0056-1.

[3] R. Pérez and A. Vidal, "Biological invasion of seas and oceans," Invasión biológica los mares y océanos, 
vol. 8, no. 3, pp. 17-28, 2011.

[4] S. A. Bailey, "An overview of thirty years of research on ballast water as a vector for aquatic invasive species to freshwater and marine environments," Aquat. Ecosyst. Heal. Manag., vol. 18, no. 3, pp. 261268, 2015. https://doi.org/10.1080/14634988.2015.1027129.

[5] R. J. Albert, J. M. Lishman, J. R. Saxena, and J. Albert, "Ballast water regulations and the move toward concentration-based numeric discharge limits," vol. 23, no. 2, pp. 289-300, 2016.

[6] International Maritime Organization, "List of ballast water management systems which received Type Approval Certification by their respective Administrations," 2017. [Online]. Available: www.imo.org. [Accessed: 05-Oct-2017].

[7] F. Yonsel and G. Vural, "KPI ( KEY PERFORMANCE INDICATORS ) APPLICATION ON BALLAST WATER TREATMENT SYSTEM SELECTION,” Brodogradnja/Shipbuilding, vol. 68, no. 3, pp. 67-84, 2017. https://doi.org/10.21278/brod68305.

[8] C. Bilgin Güney and F. Yonsel, "Electrochemical Cell Applications for Ballast Water Treatment," Mar. Technol. Soc. J., vol. 47, no. 1, pp. 134-145, 2013. https://doi.org/10.4031/MTSJ.47.1.9.

[9] F. Yonsel, C. B. Guney, and D. Bulent, "A NEURAL NETWORK APPLICATION FOR," Fresenius Environ. Bull., vol. 23, no. 12b, pp. 3353-3361, 2014.

[10] E. Tsolaki and E. Diamadopoulos, "Technologies for ballast water treatment: A review," Journal of Chemical Technology and Biotechnology, vol. 85, no. 1. pp. 19-32, 2010. https://doi.org/10.1002/jctb.2276.

[11] O. K. Hess-Erga, K. J. K. Attramadal, and O. Vadstein, "Biotic and abiotic particles protect marine heterotrophic bacteria during UV and ozone disinfection,” Aquat. Biol., vol. 4, no. 2, pp. 147-154, 2008. https://doi.org/10.3354/ab00105.

[12] G. J. Prange and N. N. Pereira, "Ship Ballast Tank Sediment Reduction Methods,” Nav. Eng. J., no. 125, pp. 127-134, 2013.

[13] L. Maglić, D. Zec, and V. Frančić, "Ballast water sediment elemental analysis," Mar. Pollut. Bull., vol. 103, no. 1-2, pp. 93-100, 2016. https://doi.org/10.1016/j.marpolbul.2015.12.042.

[14] C. Grob and B. G. Pollet, "Regrowth in ship's ballast water tanks: Think again!," Mar. Pollut. Bull., vol. 109, no. 1, pp. 46-48, 2016. https://doi.org/10.1016/j.marpolbul.2016.04.061.

[15] I. van der Star, V. Liebich, and P. P. Stehouwer, "The forgotten fraction: The importance of organismssmaller than $10 \mu \mathrm{m}$ when evaluating ballast water treatment systems," in Proceedings of the Global R\&D Forum on Compliance Monitoring and Enforcement - The Next R\&D Challenge and Opportunity, 2011.

[16] R. Brinkmeyer, "Diversity of bacteria in ships ballast water as revealed by next generation DNA sequencing," Mar. Pollut. Bull., vol. 107, no. 1, pp. 277-285, 2016. https://doi.org/10.1016/j.marpolbul.2016.03.058.

[17] E. Briski, S. a Bailey, and H. J. MacIsaac, "Invertebrates and their dormant eggs transported in ballast sediments of ships arriving to the Canadian coasts and the Laurentian Great Lakes," Limnol. Oceanogr., vol. 56, no. 5, pp. 1929-1939, 2011. https://doi.org/10.4319/lo.2011.56.5.1929.

[18] T. F. Sutherland and C. D. Levings, "Quantifying non-indigenous species in accumulated ballast slurry residuals (swish) arriving at vancouver, british columbia,” Prog. Oceanogr., vol. 115, pp. 211-218, 2013. https://doi.org/10.1016/j.pocean.2013.05.015.

[19] T. Johengen et al., "Assessment of Transoceanic NOBOB Vessels and Low-Salinity Ballast Water as Vectors for Non-indigenous Species Introductions to the Great Lakes," 2005.

[20] S. A. Bailey et al., "In situ hatching of invertebrate diapausing eggs from ships' ballast sediment," Divers. Distrib., vol. 11, no. 5, pp. 453-460, 2005. https://doi.org/10.1111/j.1366-9516.2005.00150.x.

[21] H. Mimura, R. Katakura, and H. Ishida, "Changes of microbial populations in a ship's ballast water and sediments on a voyage from Japan to Qatar,” Mar. Pollut. Bull., vol. 50, no. 7, pp. 751-757, 2005. https://doi.org/10.1016/j.marpolbul.2005.02.006.

[22] G. M. Hallegraeff, "Transport of harmful marine microalgae via ship's ballast water: Management and mitigation with special reference to the Arabian Gulf region," Aquat. Ecosyst. Heal. Manag., vol. 18, no. 3, pp. 290-298, 2015. https://doi.org/10.1080/14634988.2015.1027138.

[23] O. Casas-Monroy, S. Roy, and A. Rochon, "Dinoflagellate cysts in ballast sediments: Differences between Canada's east coast, west coast and the Great Lakes," Aquat. Conserv. Mar. Freshw. Ecosyst., vol. 23, no. 2, pp. 254-276, 2013. https://doi.org/10.1002/aqc.2310.

[24] C. Bilgin Güney, Ş. N. Ertürk Bozkurtoğlu, D. B. Danışman, and F. Yonsel, "Another Challenge: Sediments of The Ballast Tanks," in 1st International Congress on Ship and Marine Technology; "Green Technologies, " 2016.

[25] S. Banerji, B. Werschkun, and T. Höfer, "Assessing the risk of ballast water treatment to human health," Regul. Toxicol. Pharmacol., vol. 62, no. 3, pp. 513-522, 2012. https://doi.org/10.1016/j.yrtph.2011.11.002. 
[26] E. Macdonald and R. Davidson, "Ballast water project - final report, Spring 1997.” p. 81 + Plates, 1997.

[27] D. Feng et al., "Pollution characteristics and ecological risk of heavy metals in ballast tank sediment," Environ. Sci. Pollut. Res., vol. 24, no. 4, pp. 3951-3958, 2017. https://doi.org/10.1007/s11356-016-8113Z.

[28] C. Guedes Soares, Y. Garbatov, A. Zayed, and G. Wang, "Corrosion wastage model for ship crude oil tanks," Corros. Sci., vol. 50, no. 11, pp. 3095-3106, 2008. ttps://doi.org/10.1016/j.corsci.2008.08.035.

[29] K. De Baere, H. Verstraelen, L. Lemmens, S. Lenaerts, and G. Potters, "In Situ Study of the Parameters Quantifying the Corrosion in Ballast Tanks and an Evaluation of Improving Alternatives," Sh. Struct. Comm. Symp., pp. 1-16, 2011.

[30] M. N. Tamburri, K. Wasson, and M. Matsuda, "Ballast water deoxygenation can prevent aquatic introductions while reducing ship corrosion," Biol. Conserv., vol. 103, no. 3, pp. 331-341, 2002. https://doi.org/10.1016/S0006-3207(01)00144-6.

[31] A. Heyer, F. D’Souza, C. F. L. Morales, G. Ferrari, J. M. C. Mol, and J. H. W. De Wit, "Ship ballast tanks a review from microbial corrosion and electrochemical point of view," Ocean Eng., vol. 70, pp. 188-200, 2013. https://doi.org/10.1016/j.oceaneng.2013.05.005.

[32] J. P. Hamer, "Ballast Tank Sediments," Invasive Aquat. Species Eur. Distrib. Impacts Manag., pp. 232234, 2002. https://doi.org/10.1007/978-94-015-9956-6_24.

[33] W. Wilson, P. Chang, P. Verosto, Stephan Atsavapranee, D. F. Reid, and P. T. Jenkins, "Computational and Experimental Analysis of Ballast Water Exchange," Nav. Eng. J., vol. 118, no. 3, pp. 25-36, 2006. https://doi.org/10.1111/j.1559-3584.2006.tb00460.x.

[34] Z. Qi, I. Eames, and A. Greig, "Flushing ballast tanks," Ocean Eng., vol. 89, pp. 157-172, 2014. https://doi.org/10.1016/j.oceaneng.2014.07.022.

[35] Z. Qi and I. Eames, "Implications of ballast tank geometry and treatment technology on NIS removal," Ocean Eng., vol. 103, pp. 211-222, 2015. https://doi.org/10.1016/j.oceaneng.2015.04.046.

[36] R. Sturtevant, A. Ricciardi, and D. F. Reid, “Great Lakes: Recent History of Saltwater Vessel Traffic', Delivery of Ballast Water, and The Effect of Ballast Water Exchange on Aquatic Species Invasions," 2007.

[37] MEPC, "2012 Guidelines on design and construction to facilitate sediment control on ships (G12)(Resolution MEPC.209 (63)), 2012.

[38] J. Linders, "The Global R\&D Forum on Compliance Monitoring and Enforcement - The Next R\&D Challenge and Opportunity," in Finalized methodology for risk assessment of active substances under procedure (G9), 2013, pp. 141-149.

[39] M. Fettweis et al., "Monitoring the effects of disposal of fine sediments from maintenance dredging on suspended particulate matter concentration in the Belgian nearshore area (southern North Sea)," Mar. Pollut. Bull., vol. 62, no. 2, pp. 258-269, 2011. https://doi.org/10.1016/j.marpolbul.2010.11.002.

[40] C. D. Barton and A. D. Karathanasis, "Clay Minerals," in Encyclopedia of Soil Science, R. Lal, Ed. New York: Marcel Dekker, 2002, pp. 187-192.

[41] N. Bialystocki and D. Konovessis, "On the estimation of ship's fuel consumption and speed curve: A statistical approach," J. Ocean Eng. Sci., vol. 1, no. 2, pp. 157-166, 2016. https://doi.org/10.1016/j.joes.2016.02.001.

[42] J. H. Jung, H. S. Yoon, and C. Y. Lee, "Effect of natural frequency modes on sloshing phenomenon in a rectangular tank," Int. J. Nav. Archit. Ocean Eng., vol. 7, no. 3, pp. 580-594, 2015. https://doi.org/10.1515/ijnaoe-2015-0041.

[43] L. Maglić, V. Frančić, D. Zec, and M. David, "Ballast water sediment management in ports," Mar. Pollut. Bull., no. September, pp. 1-8, 2017. https://doi.org/10.1016/j.marpolbul.2017.09.065.

[44] C. Bilgin Güney, D. B. Danışman, Ş. N. Ertürk Bozkurtoğlu, and F. Yonsel, "Determination of Critical Sediment Accumulation Zones in A Balast Tank Model," J. ETA Marit. Sci., vol. 5, no. 3, pp. 290-299, 2017. https://doi.org/10.5505/jems.2017.85570.

[45] H. Yuan, P. Zhou, and N. Mei, "Numerical and experimental investigation on the ballast flushing system," Ocean Eng., vol. 130, no. December 2016, pp. 188-198, 2017.

Submitted: 16.10.2017 Ceren Bilgin Güney, bilgincer@itu.edu.tr

Devrim Bülent Danişman, bulent.danisman@itu.edu.tr

Accepted: 08.01.2018. Şafak Nur Ertürk Bozkurtoğlu, erturk@itu.edu.tr

Fatma Yonsel, fyonsel@itu.edu.tr

Istanbul Technical University, Faculty of Naval Architecture and Ocean Engineering, Department of Shipbuilding and Ocean Engineering, Maslak, 34469 Istanbul/Turkey 